\title{
KAJIAN SEMIOTIKA PADA KOLOM SUNDAY MEME DI KORAN JAWA POS EDIDI AGUSTUS-OKTOBER 2015
}

\author{
Sandi Aries Soegiarto, Sunu Catur Budiyono \\ (Pendidikan Bahasa dan Sastra Indonesia, Fakultas Keguruan Dan Ilmu Pendidikan, \\ Universitas PGRI Adi Buana Surabaya) \\ aresbundeg@gmail.com, sunucatur85@gmail.com
}

\begin{abstract}
ABSTRAK
Kajian ini membahas tentang makna meme pada kolom Sunday Meme di surat kabar Jawa Pos. Pembahasan utama yang dikaji adalah tentang makna semiotika yang digunakan dalam kolom meme hari Minggu di surat kabar Jawa Pos edisi Agustus-Oktober 2015. Penelitian ini bertujuan untuk mendeskripsikan makna semiotik meme pada kolom Sunday Meme di surat kabar Jawa Pos edisi AgustusOktober 2015. Teori yang digunakan dalam penelitian ini adalah teori semiotika yang digunakan oleh Charles Sanders Pierce. Penelitian ini termasuk penelitian kualitatif berupa penelitian deskripsi atau studi pustaka. Objek penelitian ini adalah ikon meme yang dimuat pada kolom Sunday Meme di surat kabar Jawa Pos. Metode yang digunakan adalah metode dokumentasi yang dilakukan dengan cara mengumpulkan dan mempelajari sumber pustaka yang relevan dengan objek penelitian. Hasil penelitian menunjukkan bahwa makna semiotik meme dalam kolom Sunday Meme memiliki variasi yang berbeda berdasarkan tema yang diterbitkan. Tema yang digunakan adalah, politik, pemerintahan, agama, ekonomi, dan bencana alam. Analisis meme dapat dilakukan dengan mengetahui konteks yang berkaitan dengan meme yang diterbitkan.
\end{abstract}

Kata kunci: meme, maknasemiotis, meme minggu, Jawa Pos.

\section{PENDAHULUAN}

Komunikasi dikenal dan dialami secara lahir oleh manusia. Komunikasi dapat berlangsung dimana saja, kapan saja dan dengan siapa saja. Semakin bertambah umur dan tingginya tingkat pendidikan seseorang, semakin luas pula hubungan yang dijangkaunya dan semakin luas cakrawala serta komunikasinya. Dalam komunikasi sehari-hari seseorang butuh berinteraksi dan bersosialisasi dengan dunia luar. Untuk menjalin hubungan yang harmonis, baik dengan lingkungan internalmaupun eksternal, tentu keandalan dalam berkomunikasi sangat dibutuhkan.

Definisi komunikasi secara umum, menurutMulyana (2004: 3) adalah hubungan, kontak, pengiriman, dan penerimaan berita antara dua orang atau lebih dengan cara yang tepat, sehingga pesan yang disampaikan dapat dipahami. Komunikasi adalah proses berbagi makna melalui perilaku verbal dan non verbal dan segala perilaku komunikasi melibatkan dua orang atau lebih.

Secara umum proses komunikasi terbagi atas dua tahap, yaitu komunikasi primer dan komunikasi sekunder. Komunikasi primer adalah komunikasi yang menggunakan lambing sebagai media. Lambang-lambang yang digunakan adalah bahasa, kial, isyarat, warna dan gambar. Komunikasi primer terjadi secara tatap muka antara komunikator dan komunikan, sedangkan komunikasi sekunder adalah komunikasi yang menggunakan media kedua setelah menggunakan lambing sebagai medianya. Komunikasi sekunder terjadi karena komunikan yang 
dituju berada dalam ruang dan waktu yang berbeda (relative jauh) atau jumlahnya banyak. Media yang digunakan dalam komunikasi sekunder adalah media massa (surat kabar, televise siaran, radio siaran) dan media nonmassa (surat, spanduk, telegram, telepon).

Salah satu media cetak di Indonesia adalah koran Jawa Pos. Koran Jawa Pos adalah salah satu koran dengan oplah terbesar di Indonesia. Di samping itu, koran Jawa Pos juga menjadi koran yang merakyat, maksudnya koran yang bisa dibaca dari berbagai kalangan. Di dalam koran Jawa Pos terdapat kolom sunday meme yang diterbitkan setiap seminggu sekali, dengan topik yang berbeda-beda. Maka dari itu, dengan banyaknya pelanggan dan pembaca koran Jawa Pos ini penelitian ini menarik untuk di teliti.

Meme atau yang biasa dibaca mim (secara sederhana) adalah sebuah gambar yang dikombinasikan dengan tulisan dan warna yang bertujuan untuk mengkritik, menghibur, menyampaikan ide atau gagasan. Lambang-lambang atau tanda yang ada dalam konstruksi meme memiliki keterikatan antara satu sama lain dan tidak dapat dipisahkan dalam pembentukan sebuah makna. Dari uraian di atas, maka dapat diambil sebuah judul "Kajian Semiotika pada Kolom Sunday Meme di Koran Jawa Pos Edisi Agustus-Oktober 2015”. Penelitian ini bertujuan untuk mendeskripsikan makna semiotis meme pada kolom Sunday Meme di Koran Jawa Pos periode Agustus- Oktober 2015.

\section{METODE PENELITIAN}

Pendekatan yang digunakan dalam penelitian ini adalah pendekatan kualitatif. (Bogdan dan Tailor, 1998:3) mengatakan bahwa pendekatan kualitatif sebagai prosedur penelitian yang menghasilkan data-data deskriptif, berupa katakata tertulis atau lisan dari orang-orang dan perilaku yang diamati (dalam Jurnal Buana, 2005). Penelitian ini lebih memperhatikan tentang proses dan bukan hasil atau produk. Proses yang terjadi sebuah pengamatan terhadap analisis sebuah kasus. Penelitian ini menekankan pada bentuk kualitatif deskriptif.

Teknik yang digunakan dalam penelitian adalah teknik dokumentasi. Menurut Arifin (2011 : 171) bahwa dokumentasi merupakan sejumlah besar fakta dan data yang tersimpan dalam bahan yang berbentuk dokumentasi. Sebagian data yang tersimpan berbentuk surat-surat, catatan harian, cendera mata, laporan, artefak, foto dan sebagainya. Teknik ini dipilih karena data dalam penelitian ini termasuk jenis data tulis, yaitu memeyang terdapat pada Koran Jawa Pos. Langkah-langkah yang di tempuh dalam mengumpulkan data yang diperlukan dalam penelitian adalah: mengumpulkan meme-meme di Koran Jawa Pos, mengklasifikasi data sesuai dengan permasalahan penelitian, melakukan pemahaman maknameme, mengidentifikasi fenomena objek sesuai dengan perspektik atau teori yang dipakai, dan menganalisis keseluruhan meme

Teknik analisis data adalah upaya yang dilakukan untuk mengklasifikasi, mengelompokkan data (Mahsun, 2012:243). Teknik analisis data dalam penelitian ini adalah deskriptif kualitatif. Sementara menurut (Sugiyono, 2012:9), yang dimaksud deskriptif kualitatif adalah suatu jenis penelitian deskriptif, baik berupa lisan, tulisan, maupun wujud perilaku data suatu kelompok masyarakat. Analisis data deskriptif kualitatif ini akan menghasilkan gambaran atau tentang obyek yang diteliti sejelas-jelasnya. Langkah-langkah analisis data deskriptif kualitatif adalah 
reduksi data, display data (penyajian data), dan penarikan kesimpulan dan verifikasi.

Reduksi data atau mereduksi data berarti merangkum, memilih hal-hal yang pokok, memfokuskan pada hal-hal yang penting, serta dicari tema dan polanya. Dengan demikian data yang telah direduksi akan memberikan gambaran yang lebihjelas, dan memudahkan peneliti untuk melakukan pengumpulan data selanjutnya, dan mencarinya apabila diperlukan. Reduksi data dapat dibantu dengan peralatan, seperti komputer, laptop, dan notebook. Setelah data direduksi, maka langkah selanjutnya adalah menyajikan data. Dalam penelitian kualitatif, di mana penyajian data dilakukan dalam bentuk uraian singkat, bagan, hubungan antarkategori, dan sejenisnya. Menurut Miles dan Huberman, yang paling sering digunakan untuk menyajikan data dalam penelitian kualitatif adalah dengan teks yang bersifat naratif.Dengan adanya penyajian data, maka akan memudahkan untuk memahami apa yang terjadi, dan merencanakan kerja selanjutnya berdasarkan apa yang telah dipahami tersebut. Selanjutnya oleh Miles dan Huberman disarankan agar dalam melakukan display data, selain dengan teks yang naratif, juga dapat berupa grafik, matrik, network (jaringan kerja), dan chart.

Langkah ketiga dalam analisis data dalam penelitian kualitatif menurut Miles dan Huberman adalah penarikan kesimpulan dan verifikasi. Kesimpulan awal yang dikemukakan masih bersifat sementara, dan akan mengalami perubahan apabila tidak ditemukan buktibukti yang kuat yang mendukung pada tahap pengumpulan data berikutnya.Tetapi apabila kesimpulan yang dikemukakan pada tahap awal didukung oleh bukti-bukti yang valid dan konsisten saat peneliti kembali ke lapangan mengumpulkan data, maka kesimpulan yang dikemukakan merupakan kesimpulan yang kredibel.

\section{PEMBAHASAN}

Berdasarkan penelitian yang dilakukan, peneliti memeroleh hasil berupa beberapa makna meme berdasarkan tema. Tema-tema tersebut antara lain: ekonomi, politik, agama, pemerintahan, perjuangan dan bencana.

Gambar meme dengan tema ekonomi pada umumnya membahas tentang krisis ekonomi yang dialami Indonesia akibat dari melemahnya nilai tukar rupiah terhadap dolar. Krisis ini terjadi kira-kira pada awal juli. Inflasi yang dialami Indonesia mengakibatkan naiknya beberapa harga kebutuhan pokok, terutama daging. Hal ini tentu sangat membebani masyarakat karena akan menambah beban biaya hidup sehari-hari. Pemerintah tengah berupaya mengatasi krisis tersebut dengan berbagai upaya salah satunya dengan mengeluarkan paket-paket kebijakan ekonomi yang diharapkan mampu meredam gejolak krisis.

Gambar meme dengan tema politik membahas tentang jargon khas mantan presiden RI ke-3, presiden Soeharto, yaitu“ terbukti, enak jamanku tenan". Jargon tersebut muncul sebagai kritik atau secara tidak langsung merupakan "serangan politik" untuk pemerintah. Seperti kita ketahui, Soeharto merupakan mantan ketua partai Golkar. Jadi, jargon tersebut merupakan upaya untuk melemahkan kepercayaan public terhadap pemerintah di tengah terjadinya krisis dan bencana yang tengah melanda Indonesia.

Gambar meme dengan tema agama muncul sebelum hari raya idhul adha atau hari raya kurban. Meme tersebut tidak membahas secara mendalam mengenai hari rayat ersebut, ini dapat dikatakan sebagai fenomena tahunan dan sangat 
meresahka nmasyarakat sebagai konsumen. Melainkan membahas tentang fenomena melonjaknya harga daging sapi setiap menjelang hari raya kurban. Kenaikan harga daging selalu terjadi menjelang kurban. Hal Pemerintah dituntut untuk mencari solusi dan mengatasinya hingga sampai akar permasalahannya.

Gambar meme dengan tema pemerintahan merupakan kritik atas kinerja para wakil rakyat, angota DPR, yang terkesan tidak peduli dengan nasib rakyat. Hal ini dapat dilihat dari kinerja DPR yang tidak melakukan apa-apa, melainkan hanya saling memperebutkan kursi jabatan dan saling menghina satu sama lain. Hal ini diperparah dengan tuntutan berupa kenaikan gaji serta tunjangan yang bertolak belakang dengan kinerja mereka selama ini. Sebagai anggota DPR, seharusnya lebih mementingkan kepentingan rakyat dibandingkan kepentingan pribadi.

Gambar meme dengan tema perjuangan terbit sebelum hari kemerdekaan Indonesia. Meme tersebut mengingatkan kita bahwa Indonesia tidak sepenuhnya merdeka. Indonesia masih mengalami penjajahan dari segi ekonomi. Hal ini terbukti dari kuatnya pengaruh dolar terhadap rupiah. Inflasi yang terjadi dikarenakan menguatnya dolar terhadap rupiah yang mengakibatkan krisis ekonomi di Indonesia.

Gambar meme dengan tema bencana merupakan muncul sekitar awal oktober. Meme tersebut merupakan kritik terhadap bencana kabut asap yang terjadi di Indonesia, khususnya wilayah Sumatera dan Kalimantan. Bencana tersebut terjadi karena kebakaran hutan yang sengaja dilakukan oleh oknum tertentu yang membakar hutan dengan sengaja. Kabut asap tersebut meluas hingga ke negara lain dan sangat mengganggu kesehatan karena kualitas udara yang mencapai level tidak sehat hingga berbahaya. Pemerintah harus mengambil sikap tegas terhadap oknum yang melakukan hal tersebut. Selain menyebabkan kerugian materi, bencana tersebut juga menyebabkan kerugian non materi berupa gangguan kesehatan hingga menyebabkan kematian. Sikap tegas pemerintah diharapkan dapat memberikan efek jerah serta agar tidak terulangi di kemudian hari.

Meme-meme tersebut merupakan kritik yang membangun agar Indonesia semakin lebiH baik. Hal ini terbukti dari penggunaan gambar dan tulisan yang tidak mengandung unsur SARA. Meme-meme tersebut sebatas kritik terhadap pemerintah, bukan dengan tujuan menjatuhkan melainkan dengan tujuan agar pemerintah dapat mengambil sikap yang tegas dan bijak dalam menyelesaikan masalah yang dihadapi Indonesia.

\section{SIMPULAN}

Kolom Sunday Meme merupakan salah satu contoh komunikasi nonverbal yang menggunakan tulisan dan gambar sebagai medianya. Kolom Sunday meme terbit dengan mengangkat tema tentang permasalahan-permasalahan yang terjadi di Indonesia. Tema -tema tersebut antara lain: ekonomi, politik, agama, pemerintahan, perjuangan dan bencana. Kolom tersebut berisi kritik atas keadaan yang terjadi dengan bahasa sindiran yang bertujuan agar tidak ada pihak yang dirugikan dan dilecehkan. Kolom Sunday meme memiliki makna semiotis yang tidak dapat dilepaskan dari konteks yang ada, yakni keadaan yang sedang terjadi. Dalam memaknai sebuah meme harus mengetahui konteks yang ada karena tanpa mengetahui konteks tersebut, maka tidak akan pernah dapat mengetahui makna yang ada di dalam sebuah meme. 


\section{SARAN}

Setelah melakukan penelitian ini, penulis berniat memberikan saran yang mungki bisa dijadikan motivasi untuk pembaca dan masyarakat pada umumnya agar bijak dalam menggunakan media dalam berkomunikasi. Hendaklah tidakm erugikan orang lain dengan kata-kata kasar yang melecehkan dan mengandung unsure SARA. Kebebasan berpendapat merupakan hak setiap manusia, namun bebas bukan berarti tanpa batas. Kebebasan seseorang dibatasi oleh hak setiap orang pula.

Perkembangan teknologi, hendaknya memberikan kemudahan serta kemanfaatan dalam berkomunikasi. Menjual dan membeli barang-barang melalui took online serta memberikan informasi dan mencari teman melalui media social merupakan beberapa contoh positif dalam berkomunikasi. Hal itu lebih baik, daripada kita melecehkan, berkomentar yang negative atau melakukan tindak pidan akriminal yang tidak hanya merugikan diri kita sendiri, melainkan merugikan banyak pihak.

\section{DAFTAR PUSTAKA}

Alwi, Hasan. 2007. Kamus Besar Bahasa Indonesia. Jakarta: Balai Pustaka.

Arikunto, Suharsimi. 2002. Prosedur Penelitian Suatu Pendekatan Praktek. Jakarta: PT Rineka Cipta.

Effendi, O. U. 2009. ILMU Komunikasi Teori DAN Praktek. Bandung: Rosda.

Isani, Luluk. Kulup. 2012. Berbicara. Surabaya: Adibuana press.

Kaelan. 2009. Filsafat Bahasa Semiotika dan Hermeneutika. Yogyakarta: Paradigma.

Kurniawan. 2001. Semiologi Roland Barthes. Magelang: Yayasan Indonesiatera.

Mahsun. 2012. Metode Penelitian Bahasa: Tahapan Strategi, Metode, dan Tekniknya. Jakarta: Rajawali Pers.

Moleong J. Lexy.2008. Metodologi Penelitian Kualitatif. Bandung: PT. Remaja Rosdakarya.

Piliang, Yasraf Amir. 2003. Hipersemiotika: Tafsir Cultural Studies Atas Matinya Makna. Yogyakarta: Jalasutra.

Prastowo, Andi. 2012. Metode Penelitian Kualitatif. Jogjakarta: Ar-ruzz media.

Sobur, Alex. 2006. Semiotika Komunikasi. Bandung : PT. Rosdakarya .

Sobur, Alex. 2013. Semiotika Komunikasi. Bandung :Rosda.

Sugiyono. 2012. Metode Penelitian Kuantitatif. Kualitatif, dan R\&D. Bandung: alfabeta.

Van Zoest, Art dan P. Sudjiman ) ed). 1996. Serba-Serbi Semiotika. Jakarta. Gramedia Pustaka Umum.

Vera, N. 2014. Semiotika dalam Riset Komunikasi. Bogor: Ghalia Indonesia.

http://www. Jawa pos - wikipedia bahasa indonesia. Diunduh tanggal 14 Agustus 2015 pukul 20.45

http://ssbelajar.blogspot.com/2012/11/pengolahan-datakualitatif.htmldiaksespadatanggal 24 August 2015 pukul 23:12 WIB.

http://phisiceducation09.blogspot.com/2013/03/triangulasi-dalam-penelitiankualitatif.htmldiaksespadatanggal 25 Agustus 2015 pukul 01:00 WIB. 
http://jaririndu.blogspot.com/2011/11/teori-semiotik-menurut-paraahli.htmldiunduh tanggal 25 Agustus 2015 pukul 01:03 WIB.

http://abadiaulia.blogspot.com/2012/12/teori-semiotika-dalam-

komunikasi.htmldiaksestanggal 25 Agustus 2015 pukul 01:05 WIB. 